\title{
Negotiate flexibly, but explain publicly
}

THE Royal Commission on Environmental Pollution, chaired by Sir Brian Flowers, has just reported on air pollution control (Cmnd 6371, HMSO, £1.75) and manages to handle the potentially inflammatory issue of the Alkali Inspectorate in a sensible and pragmatic way. The inspectorate is praised and criticised in about equal amounts, but no major modifications are proposed to its traditional mode of working, namely by collaboration with industry rather than by confrontation.

Air pollution control in Britain is carried out through two very separate administrative machineries. Her Majesty's Alkali and Clean Air Inspectorate is charged with overseeing a limited number of specified processes deemed to be particularly polluting or problematical. (The first of these processes was initially associated with alkali works where, from 1820 on, great clouds of hydrochloric acid gas were released in the manufacture of sodium carbonate from salt-hence the quaint name given to the inspectorate when it was established in 1863.) Inspectors have always worked on the principle that industry should use the "best practicable means" to reduce discharges rather than be held to fixed emission standards. In the course of this, the inspector has played a substantial and unsung role in the rapid transfer of information about anti-pollution technology, and has also been consulted as a matter of course before the installation of new plant. But in spite of continued advances in freeing the air of industrial pollutants, the inspectorate has come in for plenty of criticism. The "best practicable means" approach, its critics allege, can hide all sorts of abuses or agreements to go easy on polluters. The inspectorate has compounded the problem by making inadequate responses to its detractors, partly, no doubt, because inspectors feel themselves constrained by industrial secrecy and partly because staff numbers are only adequate to perform the inspecting job, not to hold colloquia or confrontations with a broader public.

The other means for controlling air pollution is through the local authority, whose environmental health officer must take care of domestic pollution and of those industries not on the inspectorate's list. Some authorities have air pollution units, but many do not, so control is patchy. Relations between the inspectorate and local authorities vary from good to bad (there is no administrative reason why they should ever meet). And for all that some cities have cleaned up the air dramatically over the past 20 years (London now has $70 \%$ more sunshine in December than it used to before smokeless zones were introduced), $40 \%$ of the nation's premises which were originally planned to be in smoke control areas have still to come under this constraint.
It is the commission's hope that by releasing the inspectorate from the Health and Safety Executive, where it never really belonged, and by subsuming it in a larger Pollution Inspectorate which could deal with other problems such as water pollution and solid waste, the necessary central expertise can be preserved and aug. mented while making it easier for local authorities to deal with this expertise. This depends on two fairly important assumptions: first, that the major problems in water and solid waste management are amenable to the same sort of negotiation that the inspectorate has evolved for air pollution. There seems no reason why they shouldn't be if a national unit is put together from existing staff in water authorities, central government and so on, but positive results may still be several years off. Second, the Pollution Inspectorate really must take its relations with the public seriously and must hire people appropriately. It cannot simply be allowed to become an expanded Alkali Inspectorate, full of very dedicated experts, employed full time in talking to industry; at least $20 \%$ of the staff should be available to talk and listen regularly to the public.

The commission talks of the housewife whose washing has been dirtied by a breakdown in pollution control at a nearby plant and who may be "disconcerted and irritated" by a request to leave a message on the District Alkali Inspector's phone answering machine (inspectors only have part-time secretarial staff!). She might be lucky even to find the right phone number. In the London Phone Directory there is nothing under "Air", "Alkali", "Clean Air", "Clean Air Council" (which advises the government on air pollution), "Her Majesty's Alkali and Clean Air Insvectorate", or "Pollution". A very smart housewife might just possibly alight on "Environment, Department of the", where lurking under a sub-subheading is "Noise, Clean Air and Waste". Or she might try her local authority for which, if the phone book is not too out-of-date there could be an entry "Environmental Health Services", but no mention of air pollution. But, of course, if it was smoke from a bus she would have to ring London Transport. And what about smoke from a car?

Nowhere is bureaucracy more anonymous than in the phone book. The first job for a new pollution inspectorate might be to follow the example of some other countries, hire some intelligent telephone-persons and put a number in the directory with the entry

AIR POLLUTION from all sourcescomplaints and queries...

No charge for this public service... 